\title{
Shifting Paradigms: Rethinking Education During and Post-COVID-19 Pandemic
}

\author{
Hlamulo Wiseman Mbhiza \\ University of Limpopo, Faculty of Education, South Africa \\ Email:wmbhiza@gmail.com \\ Received : 2021-06-14 \\ Revised : 2021-07-21 \\ Accepted : 2021-08-22
}

$10.46303 /$ ressat.2021.31

\begin{abstract}
How to cite this paper: Mbhiza, H. W. (2021). Shifting Paradigms: Rethinking Education During and Post-COVID-19 Pandemic, Research in Social Sciences and Technology, 6(2), 279-289. https://doi.org/10.46303/ressat.2021.31
\end{abstract}

This is an Open Access article distributed under the terms of the Creative Commons Attribution 4.0 International license (https://creativecommons.org/licenses/by/4.0/).

\begin{abstract}
It is uncontested that education systems globally are under constant pressure to respond to the changing needs of societies. The outbreak of Covid-19 has reminded us that the complexity of education needs responsive practices to facilitate effective teaching and learning across all levels of schooling globally. All over the world, the normative ways of teaching and learning evolved drastically in the first quarter of the 2020 academic year when teachers and students found online offerings to be the dominant option available as a consequence of the pandemic conditions. In South Africa specifically, students and teachers were thrust into virtual teaching and learning situations with the majority of them having no preparation for this shift. This conceptual paper considers education in the current and post-Covid-19 era as the greatest paradigm shift in the history of education. I examine measures taken by higher education institutions to support the provision of education to ensure learning continuation. In this paper, I provide some suggestions for carrying out educational activities during the continuing Covid19 situation. Educational leaders need to rethink content creation and content sharing and establish working communities to meet the demands of the new paradigm in education.
\end{abstract}

Keywords: COVID-19; education; paradigm shift; South Africa; access

\section{Introduction}

The Covid-19 pandemic has turned the world upside down and is a huge challenge to the education systems globally. The consequence of the pandemic in different countries includes the widespread closure of educational institutions, national borders as well as business entities, to name just a few, in attempts to decrease the number of rising infections (Maringe, 2020). In South Africa, as the country went into what is known as a 'total lockdown', so too did all the private and public colleges and universities across the country. In this paper, I critically reflect on the measures taken by the South African higher education department and institutions to ensure learning continuation through alternative pedagogies. I also critically examine the 
consequences of shifting to virtual teaching and learning situations. In this paper, I consider education during Covid-19 and the 'uncertain post-Covid-19 era' as the greatest paradigm shift in the history of education.

According to Martin and Furiv (2020), albeit the anticipated possible short-term duration of the novel coronavirus pandemic, its impact on the nature of higher education is likely to be enduring and quite significant. Accordingly, the shift to online learning and teaching may be construed as a paradigm shift, as new ways of thinking, knowing and teaching have evolved from the traditional teaching approaches into online curriculum delivery. Subject to the success of online curriculum delivery across different institutions in the country, there are opportunities for all higher education institutions to continue access in the online medium (Eickelmann \& Gerick, 2020; Huber \& Helm, 2020). To ensure effective teaching and learning in the context of online curriculum delivery, traditional universities and colleges may need to retrain their lecturers and equally consider new requirements for staffing to maximize the success of online teaching and learning (Maringe, 2020). As students learn from home in the new education paradigm, a need to rethink our pedagogies and values of lifelong learning become significant to ensure quality of learning and equitable provision of educational knowledge to students from different social and economic backgrounds. In view of the notion of paradigm shift that is central in this paper, the changes in the education systems across the world will represent a key turning point in delivering education within higher education institutions in the post-Covid-19 era.

\section{Review of related literature}

\section{Higher Education and Covid-19}

The Covid-19 pandemic is causing major disruptions to the higher education sector, resulting in a revolution in the global landscape of higher education due to the rampant spread of the virus. As mentioned above, the pandemic has forced global higher education institutions to experiment with remote online teaching and learning. That is, because of the institutions' inability to continue delivering educational knowledge through on-campus learning, they have scrambled to provide the curricular contents through emergency online teaching. Within the South African context, universities are doing a lot of 'digital growing up' in action, especially considering that the majority of the institutions offered their various programs through oncampus teaching before Covid-19, without developed infrastructure to meet the demands of online teaching (Maringe, 2020). With the exception of the University of South Africa and some private higher education institutions which offered distance teaching and learning before the pandemic, it is highly unlikely that most of the South African universities will have enough experience to adapt and deal with distance learning effectively.

Online curriculum delivery in these times of the Covid-19 pandemic has since become a choice in teaching approaches across different universities, both private and public in South Africa and has become a key condition to ensure the continuation of learning and teaching. Until March 2020, the traditional teaching situation at the majority of South African public universities was pigeonholed by students who gathered in physical lecture halls and lecturers who presented their subjects' standard curriculum through lecturing approaches (Lipowsky \& Rzejak, 2015). The continuing changes in the national lockdown alert levels and consequently the shutting 
down of universities for physical attendance of lectures confronted both lecturers and students with an entirely new situation, which to many traditional universities was an unfamiliar way of content delivery, as mentioned earlier (Eickelmann \& Gerick, 2020; Huber \& Helm, 2020; Tarman, 2020). While the transition to online curriculum delivery through the use of various digital tools such as Blackboard, Microsoft Teams, Zoom, Google Meet, and YouTube made learning and teaching continuation possible, we should be cognizant of the extent to which these platforms effect the quality of teaching, students' learning and understanding as well as development and attainment of skills essential to specific professions.

Of importance to note is that before March 2020, neither students nor lecturers from traditional universities really knew how to navigate through the distance mode of learning and teaching. Maringe (2020) argues that, "Mere posting of teaching and learning materials on platforms such as SAKAI without the underpinning Pedagogies is likely to negatively affect both quality and effectiveness of students' learning". This necessitates that universities should train both their staff and students on the use of various platforms to ensure effective teaching, learning and assessments through online tools.

\section{The impact of technology on students and lecturers}

The era when lecturers relied on printed materials for their teaching has shifted to a technological era where lectures are integrated with various virtual platforms (Mahaye, 2020). This represents a paradigm shift in higher education from traditional face-to-face lectures to technology-based curriculum delivery. While this is the case, Sintema (2020) has argued that fewer developing countries are prepared to implement online education due to lack of experience and training, which is further exacerbated by inadequate resources to enable online curriculum delivery. Notwithstanding this reality, the advent of online education during Covid19 has created opportunities for both lecturers and students to access from online various learning materials despite the distance created by the pandemic (Hodges et al., 2020; Molise \& Dube, 2020). Of importance to note is that the pandemic has decentered lecturers by shifting more responsibilities for learning to the students. This resonates with Mahlaba's (2020) assertion that "we should not keep our students permanently dependent on us (as teachers) for their learning, because we will not always be there to provide learning" (p. 123). Covid-19 has proven that, as teachers, we will not always be readily available to be the source of information for our students, hence we should allow students to take charge of their own learning. This is not to say that lecturers should not play an active role in teaching the students, but rather to ensure that students share power in constructing educational knowledge and selfdirecting their learning (Kopish \& Marques, 2020). Various authors have argued that selfdirected learning is one of the best predictors of academic success (Khiat, 2017; Mahlaba, 2020; Tekkol \& Demirel 2018). Hedding et al. (2020, p. 1) argue that shifting to online technologybased teaching and learning "encourages a move away from 'rote learning' to focus more on problem solving, critical thinking and applied understanding by using a holistic and integrated approach, because traditional assessment techniques are no longer viable".

In relation to the above, Bester and Brand (2013) have reported that students have the ability to reconnoiter new ideas, construct knowledge and connect new information to real-life situations, which can enable effective learning if the learning environment is technology rich. Similarly, Mahaye (2020, p. 13) posits that "a major impact of Technology is that it can be used 
to enhance access to information and improve learning standard". This demonstrates that technology not only provides avenues for continuous curriculum delivery in institutions of higher learning, but also creates opportunities for effective teaching and learning. To maximize effective teaching and learning during the Covid-19 pandemic, Morgan (2020) provides a useful reflective summary of the International Society for Technology in Education's guidelines on how to use online distance teaching and learning to benefit students during the Covid-19 pandemic. The key takeaway from these guidelines are to ensure the provision of effective online education access and equity, use free high-quality resources, respond to the emotional pressures, and provide student-facing teaching and learning.

The pandemic represents a unique teaching and learning opportunity for both lecturers and students to critically reflect on the future of education. According to the World Economic Forum (2020), many students and educators have realized that it is possible to teach and learn differently, which provides the potential for a paradigm shift in education. For example, the large-scale rollout of online learning as an alternative form of curriculum delivery has created new forms of innovative teaching and learning, which could have been considered unfeasible prior to the Covid-19 pandemic. The way we understood teaching and learning at universities is changing, and the change can be unequivocally permanent.

\section{Understanding the paradigm shift}

The prognostication for a paradigm shift in education post Covid-19 is vested in the observation that higher education institutions are confronted with the task of employing alternative ways of teaching, learning and research, which are compounded by the uncertainty of what will happen in the future. As institutions across the country continue with the project of salvaging academic years in the midst of the virus, the ceremonial norms and traditions cannot continue as normal, especially considering the incommensurability of online and on campus learning and teaching approaches. Both staff and students in traditional universities will need to become knowledgeable about complex and dynamic scholarship of distance teaching and learning in order to be effective in teaching and learning within the new paradigm (Mavundla \& Mgutshini, 2021). Similarly, Mhlanga and Moloi (2020, p. 8) postulate that, "we see this change as the beginning of the process that will move education to 4IR where learning will be mostly digital, with a few occasions of face-to-face engagements". This highlights that the Covid-19 pandemic has transformed what we had come to know as the normal mode of teaching and learning in the education sector. Institutions of higher learning within the South African context are now intensifying their efforts towards offering online curriculum delivery using various learning platforms, with limited conversations about education post the pandemic. It could be argued that the forced shift to online teaching and learning has had a great influence on the higher education sector's adoption of various Fourth Industrial Revolution tools.

With above discussion in mind, the question of social justice, equity and access within the South African context cannot be overlooked whenever educational processes and provision are discussed (Mhlanga \& Moloi, 2020), especially for students located in remote rural communities and other previously disadvantaged communities. This resonates with Maringe's (2020, p. 1) argument that, "issues of exacerbating inequalities for the already disadvantaged students have to be interrogated and mitigated lest the gains already achieved may be wiped out in an instant". According to Dube (2020, p. 1), "rural learners face unprecedented 
Mbhiza, H. W. Shifting Paradigms: Rethinking Education During and Post-COVID-19 Pandemic

challenges in adjusting to a new mode of life and learning". While this refers to primary school and secondary school learners, the same can be said about university students from deprived geographic locations, especially first year students who have limited experience and training in using technological tools for learning. To exemplify this, the distinctive rise of online learning meant that students needed to secure study materials such as laptops to ensure learning continuation and completion of online assessment, which is a challenge for rural constituencies because of the high levels of poverty (Mukuna \& Aloka, 2020). This did not only create inequities in formal and epistemological access for rural students, but caused an emotional toll too, because they were reminded by the pandemic that access is for the select few.

In addition to the above discussion, most of the students in public universities in South Africa rely solely on various bursaries offered by the government to pay for tuition, accommodation, food as well as an allowance because they come from poor backgrounds and their parents are unable to afford the university fees (Masutha, 2020; Beaunoyer et al., 2020). Thus, the indefinite closure of universities means the great loss of a fundamental safety net, including nutrition, learning resources and emotional support (Odeku, 2021; Masutha \& Naidoo, 2021). I argue that the Covid-19 pandemic exacerbates social exclusion through education and the accompanying continuing inequalities brought about by the apartheid education system. For example, across the different traditional universities in South Africa, the lack of adequate access for the student in the transition to online learning has intensified exclusion and constrained effective learning. This is true, especially considering the fact that the suddenness to transit to online learning left little time for institutions to lay the groundwork for lecturers to teach online and for students to adapt to learning remotely. Thus, the normative ways universities delivered curriculum content before Covid-19 will certainly be incompatible with the anticipated postCovid-19 era. The new paradigm requires the use of vast modern-day e-learning tools and devices, as opposed to the face-to-face physical attendance of classes (Jimola \& Ofodu, 2021).

Another aspect that is observably a driver for a paradigm shift in education is that the pandemic is also forcing institutions to rethink and restructure assessment methods as well as how to conduct work-integrated learning and other practical work in an online mode. According to Almonacid-Fierro et al. (2021), "the Covid-19 pandemic has generated a profound change in education systems during 2020, impacting the teacher training processes in tertiary education" (p. 72). Such ostensibly insurmountable matters discussed herein are undeniably key drivers of a paradigm shift to our ways of knowing, ways of thinking as well as ways of being within the landscape of higher education. The change of assessment systems in universities to a new shape is one of the characteristics of the new educational paradigm, especially when the prevailing discourse of Artificial Intelligence (AI) or the Fourth Industrial Revolution (4IR) in education is seriously taken into consideration. It can be said that lecturers may resort to Al to deal with evaluation, assessment and monitoring of students' performance. Accordingly, the forced and hurried changes brought by the pandemic within South African universities serve as revolutionary in the education system.

\section{Platforms used to ensure that learning progresses}

The continuing fluctuation of the Covid-19 positive cases and the alteration of the alert levels for lockdown in South Africa constantly forces universities and other institutions of higher learning to continue using online remote learning. In this regard, UNESCO has recommended 
various resources, platforms and educational applications, depicted in Table 1, with the aim of facilitating learning continuation as well as to provide social interactions and care during closure of the institutions (Mhlanga \& Moloi, 2020). In most traditional universities in South Africa, the use of the different virtual platforms has meant learning in action, as these platforms had never formed part of their pedagogical approaches or curriculum delivery under normal circumstances. Due to space limitations in this paper, I will not unpack the use of each platform in detail, but offer insights into what the shift to using them represents within the higher education sector.

Table 1. Online learning platforms

\begin{tabular}{|c|c|}
\hline Platform & Platform Descriptions \\
\hline Microsoft Teams & $\begin{array}{l}\text { - Used by lecturers and students to hold online discussions } \\
\text { - Chat, audio calls, video calls and collaboration features }\end{array}$ \\
\hline Google Meet & $\begin{array}{l}\text { - Used by lecturers and students to hold online discussions } \\
\text { - Video meeting recordings and screen sharing }\end{array}$ \\
\hline $\begin{array}{l}\text { Online } \\
\text { (Websites) }\end{array}$ & - Learners learn independently at home \\
\hline $\begin{array}{l}\text { Blackboard } \\
\text { (Collaborate) }\end{array}$ & $\begin{array}{l}\text { - Used by lecturers and students to hold online discussions } \\
\text { - Live interaction, teach with screen sharing or using a whiteboard, } \\
\text { having breakout rooms }\end{array}$ \\
\hline Zoom & $\begin{array}{l}\text { - Used by lecturers and students to hold online discussions } \\
\text { - Video and audio conferencing, collaboration, chat, webinars, } \\
\text { breakout rooms }\end{array}$ \\
\hline Skype & $\begin{array}{l}\text { - Used by lecturers and students to hold online discussions } \\
\text { - Video and audio calls with talk, chat and collaboration features }\end{array}$ \\
\hline WhatsApp & $\begin{array}{l}\text { - Used by lecturers and students to hold online discussions and used } \\
\text { by learners to engage in collaborative learning } \\
\text { - Video and audio calls with talk, chat and collaboration features }\end{array}$ \\
\hline
\end{tabular}

The platforms depicted in Table 1 represent some of the steps taken by the South African higher education institutions to ensure learning continuity, give students support during Covid-19 and in turn strengthen online learning (see Dipa, 2020). Of importance to note is that most of the platforms in Table 1 offer multiple functionalities as described, and the majority of both students and lecturers are confronted with the task of learning how to use the platforms to interact during teaching and learning processes. The platforms represent change in what we had come to know and think about teaching and learning at traditional higher education 
institutions in South Africa, and marks the beginning of a paradigm shift to 4IR, whereby teaching and learning will be predominately digital, with limited occasions of physical interactions. Thus, it could be said that Covid-19 did not only have a major influence on the higher education sector's use of several 4IR tools, but forced a paradigm shift in the sector's normative ways of doing things.

What stands out from the prominent platforms is that the institutions have established discussion platforms to enable students and lecturers to discuss the topics in similar ways they used to in the traditional lecture environment. This demonstrates that South African higher education institutions are making strides to promote students' interactions through discussion boards featured in most of the platforms in Table 1. While this is the case, it should be noted that the nature of interactions in online platforms versus the traditional face-to-face lectures represents two different communicative approaches. Generally, pulling the platforms in Table 1 together reveals that during Covid-19 the universities are trying to configure strategies to restructure teaching and learning processes and ensure that teaching and learning continues. The recent surges of the Covid-19 virus in South Africa and the second year of using 4IR tools to deliver curriculum content to students across different institutions symbolizes what is often referred to as 'the new normal'.

Such normalcy in this paper is viewed as a paradigm shift as the behavior of the pandemic illustrates the high possibilities that the higher education system will never revert back to what it was before March 2020. In this vein, the World Health Organization (WHO) has pointed out that the novel coronavirus may never be exterminated; as such we will have to live with it. WHO emergencies expert Mike Ryan on 13 May 2020 stated that:

It is important to put this on the table: this virus may become just another endemic virus in our communities, and this virus may never go away. HIV has not gone away, but we have come to terms with the virus. I think there are no promises in this and there are no dates. This disease may settle into a long problem.

This statement captures the essence of a paradigm shift in different spheres of our lives, including the educational system globally. Things will never be how they were before the pandemic; as such we need to configure effective ways to provide educational knowledge to the students.

\section{Cheating practices}

Literature on online curriculum delivery has advocated the need to build collaborative online learning communities whereby students are continuously and actively engaged (Espasa \& Meneses, 2010; Kuo et al., 2014). According to Cross (1998), learning communities entail "groups of people engaged in intellectual interaction for the purpose of learning" (p. 4). While I consider that students' interactions in an online learning environment play a major role in their learning and academic achievements, there has been a notable outcry about students' collaboration to cheat. When the transition to online teaching and learning was made in different institutions due to Covid-19 conditions, students started using social instant messaging applications such as WhatsApp and Telegram, often removed from the direct supervision and involvement of lecturers, to exchange answers to assessment questions. This addresses the drawback of online learning and assessment to be the intensifying cheating 
practices (Mavundla \& Mgutshini, 2021; Rahim, 2020). Accordingly, as much as the shift to online teaching and learning through the utilization of 4 IR tools provides learning opportunities for students in these unprecedented times, equally the shift creates challenges, which institutions need to address if the use of online teaching and learning is to be effective (Lowenthal \& Snelson, 2017).

According to Church and de Oliveira (2013), WhatsApp is prominent because of the communication advantages it presents, including the ability to send instant messages to an individual and/or groups simultaneously, the privacy it offers, as well as being low cost. The reality is that students use these benefits to cheat in real-time during assessments since lecturers cannot supervise them as they write away from campuses. This resonates with previous studies that argue that the contemporary generation of students hold a fluid viewpoint of what unethical behavior is, compared to students in the past (Gulli et al., 2007; Troop, 2007). While it could be argued that the use of online platforms such as WhatsApp help learning communities collaborate and share information, the institutions claim that the cheating mechanisms students use not only hinder the trustworthiness of online assessments, but the quality of students' learning. In relation to this, Adedoyin and Soykan (2020, p. 5) state that "in online learning, assessments are often carried online whereby instructors are limited to proxy supervision of learners, making it impossible to regulate and control cheating". Thus, I argue that the paradigm shift creates an epistemological muddle in which students fail to observe the traditional conceptualization of academic treachery as they cheat in assessments.

\section{Conclusion}

The transition to online curriculum delivery in higher education has changed how students and lecturers relate to educational knowledge. In the context of Covid-19, the relentless usage of $4 I R$ technology for teaching and learning means that the traditional pedagogies are being disrupted, and all educational stakeholders need to adapt to the new ways of teaching and learning. What once required a visit to a library before Covid-19 is now no further away than on digital gadgets such as cell phones and laptops. While teaching and learning processes in traditional education institutions once required that students and lecturers convene in physical lecture halls, the relentless rise in Covid-19 infections in the country has forced us into the ' $4 I R$ age', where students can interact with their instructors and with each other virtually. In this paper, I demonstrated that the forced transition to online learning is driving what we might refer to as a paradigm shift in education. This means that the education system before the Covid-19 pandemic, the one that served for centuries, may no longer be compatible in this changing environment, thereby signifying an educational system revolution. Accordingly, Covid-19 has forced the education sector to be responsive to the apparent signs of the new paradigm, and we need to use the ongoing experiences of online teaching and learning to shape our expectations of what is to take hold within the education sector post the Covid-19 pandemic.

Educational leaders need to rethink content creation and content sharing, and establish working communities to meet the demands of the new paradigm in education. We can develop a hypothesis using our current experiences of online curriculum delivery, a model of online education that captures the new ways of knowing and new ways of thinking about educational processes. Such a model would be used as a tool for understanding the conditions of teaching 
and learning in the new paradigm, as well as the enablers and constraints for effective teaching and learning. This paper has demonstrated that Covid-19 has posed challenges in the education sector in South African higher education institutions, resulting in the emergence of a new paradigm through the adoption of various steps to facilitate learning in the higher education sector. With the unavoidable revolution in the education system, the South African government and higher education institutions should strengthen their resources to run online educational activities indefinitely. As demonstrated by Mike Ryan's statement earlier, should Covid-19 become another endemic virus within our communities, the education sector should be prepared to continue working in online spaces; online learning may never go away.

\section{References}

Adedoyin, O. B., \& Soykan, E. (2020). Covid-19 pandemic and online learning: the challenges and opportunities. Interactive Learning Environments, 1-13. https://www.tandfonline.com/doi/full/10.1080/10494820.2020.1813180

Almonacid-Fierro, A., Souza de Carvalho, R., Castillo-Retamal, F., \& Almonacid, M. (2021). The practicum in times of Covid-19: Knowledge developed by future physical education teachers in virtual modality. International Journal of Learning, Teaching and Educational Research, 20(3), 68-83.

Beaunoyer, E., Dupéré, S., \& Guitton, M. J. (2020). COVID-19 and digital inequalities: Reciprocal impacts and mitigation strategies. Computers in human behavior, 111, 106424.

Bester, G., \& Brand, L. (2013). The effect of technology on learner attention and achievement in the classroom. South African Journal of Education, 33(2).

Church, K., \& de Oliveira, R. (2013). What's up with WhatsApp? Comparing mobile instant messaging behaviors with traditional SMS. Proceedings of the 15th International Conference on Human-computer Interaction with Mobile Devices and Services (pp. 352-361). ACM.

Cross, K. P. (1998). Why learning communities? Why now? About campus, 3(3), 4-11.

Dipa, K. (2020, April 27). Covid-19 Presents Curricula Crunch for SA's Universities. https://www.iol.co.za/saturday-star/news/covid-19-presents-curricula-crunch-for-sasuniversities47191206

Dube, B. (2020). Rural online learning in the context of COVID 19 in South Africa: Evoking an inclusive education approach. Multidisciplinary Journal of Educational Research, 10(2), 135-157.

Eickelmann, B., \& Gerick, J. (2020). Lernen mit digitalen Medien. Zielsetzungen in Zeiten von Corona und unter besonderer Berücksichtigung von sozialen Ungleichheiten. In D. Fickermann \& B. Edelstein (Hrsg.), "Langsam vermisse ich die Schule ...". Schule während und nach der Corona-Pandemie (pp.153-162). Waxmann. doi:10.31244/9783830992318.09

Espasa, A., \& Meneses, J. (2010). Analysing feedback processes in an online teaching and learning environment: an exploratory study. Higher education, 59(3), 277-292.

Gulli, C., Kohler, N., \& Patriquin, M. (2007). The great university cheating scandal. Maclean's, 120(5), 32-36. 
Mbhiza, H. W. Shifting Paradigms: Rethinking Education During and Post-COVID-19 Pandemic

Hedding, D. W., Greve, M., Breetzke, G. D., Nel, W., \& Van Vuuren, B. J. (2020). COVID-19 and the academe in South Africa: Not business as usual. South African Journal of Science, 116(7-8), 1-3.

Hodges, C., Moore, S., Lockee, B., Trust, T., \& Bond, A. (2020). The difference between emergency remote teaching and online learning. Educause Review, 27(1), 1-9.

Huber, S. G., \& Helm, C. (2020). COVID-19 and schooling: evaluation, assessment and accountability in times of crises - reacting quickly to explore key issues for policy, practice and research with the school barometer. Educational Assessment, Evaluation and Accountability, 32(2), 237-270.

Jimola, F. E., \& Ofodu, G. O. (2021). Sustaining learning during COVID-19 seismic shift: The need to develop flexible pedagogy. Interdisciplinary Journal of Education Research, 3(1), 14-26.

Khiat, H. (2017). Academic performance and the practice of self-directed learning: The adult student perspective. Journal of Further and Higher Education, 41(1), 44-59.

Kopish, M., \& Marques, W. (2020). Leveraging technology to promote global citizenship in teacher education in the United States and Brazil. Research in Social Sciences and Technology, 5(1), 45-69.

Kuo, Y. C., Walker, A. E., Schroder, K. E., \& Belland, B. R. (2014). Interaction, Internet selfefficacy, and self-regulated learning as predictors of student satisfaction in online education courses. The Internet and Higher Education, 20, 35-50.

Lipowsky, F., \& Rzejak, D. (2015). Key features of effective professional development programmes for teachers. Ricercazione, 7(2), 27-51.

Lowenthal, P. R., \& Snelson, C. (2017). In search of a better understanding of social presence: An investigation into how researchers define social presence. Distance Education, 38(2), 141-159.

Mahaye, N. E. (2020). The impact of COVID-19 pandemic on education: navigating forward the pedagogy of blended learning. Available at https://www.academia.edu/42842598/The Impact of COVID 19 Pandemic on Educ ation Navigating Forward the Pedagogy of Blended Learning

Mahlaba, S. C. (2020). Reasons why self-directed learning is important in South Africa during the Covid-19 pandemic. South African Journal of Higher Education, 34(6), 120-136.

Maringe, F. (2020). The Quarantined Academy: Emerging Opportunities and Risks. Heltasa. http://heltasa.org.za/the-quarantined-academy-emergingopportunities-and-risks/

Martin, M., \& Furiv, U. (2020). COVID-19 shows the need to make learning more flexible. University World News. The Global Window on Higher Education. https://www.universityworldnews.com/post.php?story=20200324115802272

Masutha, M. (2020). Redressing or Reproducing Inequalities? Narrative Accounts of Workingclass Students' Experiences of Completion and Non-completion in South African Higher Education. Unpublished doctoral dissertation, University of Bath.

Masutha, M., \& Naidoo, R. (2021). Stories from the Margins. In M. K. Ralarala, S. L. Hassan, \& R. Naidoo (Eds.), Knowledge Beyond Colour Lines: Towards Repurposing Knowledge Generation in South African Higher Education, (pp. 59-77). UWC Press.

Mavundla, A. O., \& Mgutshini, T. (2021). Contexts during the Covid-19 pandemic in South Africa. Covid-19. In T. Mgutshini, K. Oparinde, \& V. Govender (Eds.). Covid-19: 
Mbhiza, H. W. Shifting Paradigms: Rethinking Education During and Post-COVID-19 Pandemic

Interdisciplinary Explorations of Impacts on Higher Education (pp. 97 - 111). African Sun Media.

Mhlanga, D., \& Moloi, T. (2020). COVID-19 and the Digital Transformation of Education: What Are We Learning on 4IR in South Africa? Education Sciences, 10(7), 180.

Molise, H., \& Dube, B. (2020). Emergency online teaching in Economic and Management Sciences necessitated by the COVID-19 pandemic: The Need for Healthy Relations in a Rural Schooling Context. International Journal of Learning, Teaching and Educational Research, 19(6), 387-400.

Morgan, H. (2020). Best practices for implementing remote learning during a pandemic. The Clearing House: A Journal of Educational Strategies, Issues and Ideas, 93(3), 135-141.

Mukuna, K. R., \& Aloka, P. J. (2020). Exploring Educators' Challenges of Online Learning in Covid-19 at a Rural School, South Africa. International Journal of Learning, Teaching and Educational Research, 19(10), 134-149.

Odeku, K. O. (2021). Using Blackboard Collaborate for Law Pedagogy Amid a Spiraling Covid19 Pandemic in a Historically Disadvantaged Black South African University. Journal of Educational and Social Research, 11(3), 241-241.

Rahim, A. F. A. (2020). Guidelines for online assessment in emergency remote teaching during the COVID-19 pandemic. Education in Medicine Journal, 12(2), 59-68.

Sintema, E. J. (2020). E-Learning and Smart Revision Portal for Zambian Primary and Secondary School Learners: A Digitalized Virtual Classroom in the COVID-19 Era and Beyond. Aquademia, 4(2), ep20017. https://doi.org/10.29333/aquademia/8253

Tarman, B. (2020). Reflecting in the shade of pandemic. Research in Social Sciences and Technology, 5(2), i-iv.

Tekkol, i. A., \& Demirel, M. (2018). An investigation of self-directed learning skills of undergraduate students. Frontiers in psychology, 9, 2324.

Troop, D. (2007). You're never gonna believe this one. Chronicle of Higher Education, 53, 4. http://www.chronicle.com/article/youre-never-gonna-believe/16333

World Economic Forum. (2020). The Future of Jobs Report 2020. https://www.voced.edu.au/content/ngv:88417 